\title{
ЯЗЫКОЗНАНИЕ
}

UDC 811.113.4

Yulia Avakova

Moscow State Institute of International Relations (University)

of the Ministry of Foreign Affairs of the Russian Federation

\section{THE DARK SIDE OF DANISH HYGGE: NEOLOGISMS HYGGERACISME AND HYGGESEXISME, THEIR MEANING AND TRANSLATION OPTIONS}

For citation: Avakova Yu. The dark side of Danish hygge: Neologisms hyggeracisme и hyggesexisme, their meaning and translation options. Scandinavian Philology, 2020, vol. 18, issue 1, pp. 5-20. https://doi.org/10.21638/11701/spbu21.2020.101

The article explores the concept of Danish hygge as an integral part of Danish language consciousness. Two peculiar concepts that have been coined relatively recently (namely hyggeracisme and hyggesexisme) have already managed to gain a certain popularity with the Danish media, notwithstanding the said expressions' obvious ambiguity. On the one hand, these terms encompass a variety of shades of meaning intrinsic to the concept of hygge, on the other hand, they have more to do with some marginal interpretations of hygge, rather than with more conventional perceptions of the phenomenon. The "dark side" of Danish hygge has often been the subject of social science research, though one must admit, somewhat regrettably, that it has not been thoroughly examined in regard to translation. Being a widely accepted social phenomenon, it deserves further investigation. In order to proceed with the task at hand and to correctly delineate the actual meaning of these neologisms, one must embrace the semantic limitations of the hygge concept, simultaneously drawing distinctions between the positive, neutral and negative impacts of hygge on everyday life. Furthermore, if one takes a more detailed look at such basic concepts as 'racism' and 'sexism', one will see that these have different implications for the Danish and Russian languages due to the various cultural, historical, and institutional differences between the two countries, although the core meaning seems to remain intact. These differences, however minimal, may become substantial enough to negate the possibility of employing direct equivalents 
for translation purposes. When such notions as 'racism' and 'sexism' merge with 'hygge-', the compound nouns seem to undergo a drastic semantic transformation - the original meaning gives way to a new one, much more obscure (thus making literal translation inadequate). The next step includes choosing the most feasible strategies for translation. Due to the fact that we are dealing with a neologism that is widely used, though not particularly consistently, one must always take into consideration the intentions of the speaker who usually makes references to Danish social and cultural realities that are not always entirely known to an outside observer. The article includes the main views on the notion of "hygge" in all its aspects, providing contextual examples of the occurrence of both neologisms, along with possible translations and justifications for the choices made by the author.

Keywords: Danish language, "hygge", hyggeracisme, hyggesexisme, neologism, racism, nationalism, sexism, sociolinguistics, translation.

\section{INTRODUCTION}

The concept of "hygge" is an integral feature of Danish language consciousness and is familiar to anyone who deals with Danish in an academic or professional capacity. Moreover, recent developments indicate that "hygge" has gained rather an unexpected popularity internationally, having become a cultural metaconcept. This quintessential Danish interpretation of "cosiness" ("уют" in Russian) has been the subject of numerous books and articles written in Danish, English and Russian, and addressed to a broader audience.

The vast majority of works dedicated to "hygge" view it merely as a new and attractive, but not yet widely-known, behavioral concept akin to "mindfulness" or "positive thinking", exploring the potential of its application, while the concept itself can be understood solely through a specific set of values inherent in the culture, from which it originated. In the absence of such an approach it will be quite difficult to analyse and understand some of the more subtle social phenomena, reflected in the Danish language. This can be exemplified by the presence of such quaint (and at a first glance nonsensical) neologisms with overtly negative connotations as "hyggeracisme" (hygge racism) and "hyggesexisme" (hygge sexism) among a number of others in modern Danish.

This article aims to define the intrinsic meaning of such newly emerged notions, hyggeracisme and hyggesexisme for instance, exploring the usage of these terms along with outlining some possible strategies for translation into Russian. In order to achieve this objective one has to solve a number of smaller issues, such as: 1) establishing the scope 
of the concept of "hygge"; 2) determining the community values that "hygge" embodies, including socially beneficial and detrimental strategies for their realisation; 3 ) defining hyggeracisme and hyggesexisme, and describing the range of problems one may encounter when attempting to provide an accurate translation - this goal can be attained by providing several examples of language use from Danish mass media and works of fiction.

\section{HYGGE AS A SOCIAL AND CULTURAL PHENOMENON}

The most well-known work on "hygge" that has greatly contributed to the international popularisation of "hygge" is Meik Wiking's The Little Book of Hygge: The Danish Way to Live Well, first published in English in 2016 [Wiking, 2016], promptly followed by a plethora of generic and at times less well-structured literature on the same subject, now available in a variety of languages. To name a few: Hygge: The Danish Art of Happiness by Marie Tourell Søderberg [Tourell Søderberg, 2016], The book of hygge. The Danish art of living well by Louisa Thomsen Brits [Thomsen Brits, 2016], The Year of Living Danishly: Uncovering the Secrets of the World's Happiest Country by Helen Russell [Russell, 2016], etc.

It was quite expected that an array of books following a similar format on related topics would emerge. Now one can find books on cultural trademarks of other Scandinavian countries, such as Swedish "lagom" [Dunne, 2017] and "fika" [Balslev, 2018], Finnish "sisu" [Nylund, 2018], and "kalsarikanni" [Rantanen, 2018]. However, at least in Russia, due to the order with which Scandinavian-related publications appeared, it was "hygge" that became most well-known and paved the way for interest in Nordic-style ways of creating cosiness, very well-known in Russia under the guise of “уют".

Russian research literature on "hygge" can boast a number of papers where this concept was studied in its linguistic dimension pertaining to Danish [Krasnova, 2016] and in comparison to a similar Norwegian concept [Livanova, 2019].

The vast majority of academic works related to "hygge" explore it from a sociological viewpoint - with regard to the proxemics of Danish daily life [Hansen, 1976], and in connection with Danish middle-class values [Linnet, 2011], with a view to describing the foundations of the 
national identity [Jenkins, 2014], in the context of cultural semantics and cultural cognition [Levisen, 2012], and in light of the paradoxical crossroads between socially accepted forms of behavior and latent nationalism [Pessel, 2018].

Almost none of the researchers offer a clear-cut definition of "hygge", however, the approximate scope of this notion and its widest possible meaning can be inferred through comparing existent interpretations. The American anthropologist Jonathan M.Schwartz lists three "graces of Danish culture and socialization" obvious to every foreigner: hygge (cosiness), tryghed (security), and trivsel (well-being) [Cit. ex: Levisen, 2012, p. 1].

Carsten Levisen states that "hygge" implies what one may call "social intimacy" and a basic "trust" in the inclusiveness and good intentions of the other people present" [Levisen, 2012, p. 93], but at the same time "hygge" "cannot be achieved if there is disagreement and conflict in the group or if there is a sense of distrust between people" [Levisen, 2012]. "Hygge" is per se a fragile state, as it possesses both static and dynamic characteristics - on the one hand "hygge" denotes "a process" and on the other hand it constitutes "a goal", it can appear and fade away just as quickly [Levisen, 2012, p. 104]. Furthermore, despite its unifying potential, hygge, in a way, separates "those in the know" (the Danes in this instance) from all others who cannot experience "hygge" from within, as they do. Carsten Levisen notes that there can be no French, Finnish, or any other national version of "hygge" as it "sounds odd in speakers' minds" and is "linked" to Danishness and ultimately to the place "Denmark" [Levisen, 2012, p. 90].

Stephen Borish points out, that hygge requires 1) complete and positive participation; 2) a sustained back-and-forth dance of involvement; 3 ) the use of positive social skills, including teasing (a national pastime); 4) quick repartee; 5) the telling of stories and jokes; 6) patience; 7) sensitivity; 8) an ability to be an enthusiastic audience [Cit. ex: Linnet, 2011, p.24]. Teasing as a "national pastime", mentioned above, seems to be not only an astute observation, but one of utmost importance with regard to the subject of the article and will be examined later in its entirety.

Jeppe Trolle Linnet sees a connection between hygge and egalitarian values, underlining the importance of a "middle-class worldview" in the development of this concept [Linnet, 2011, p. 24]. Among other 
things, hygge "facilitates the day-to-day exercise of social control" [Linnet, p.29]. Thus, one can conclude that "hygge" constitutes a means of attaining behavioral normativity and creates a sense of belonging to a well-off and stable social group no less than Victorian values did for Britain in the XIX century.

When Judith Friedman Hansen talks about the way physical space and proxemics influence relationships among people, she mentions "hygge" as something, that is considered "to be typically (even quintessentially) Danish" [Friedman Hansen, 1976, p. 54]. According to her analysis, there are four essential elements fundamental to "hygge": comfort, cosiness, cheerfulness, and friendliness. Among the additional characteristics in regard to public and private spaces, "familiarity"stands out as being "more than a habitual state of affairs" and includes a connection with the past, history, and joyful moments [Friedman Hansen, 1976, p. 54]. Predictability and moderation also seem to embody the sort of virtues that "hygge" encompasses [Friedman Hansen, 1976, p. 55].

The conclusions drawn by J.F. Hansen and J. T. Linnet were further developed in an article written by Włodzimierz Karol Pessel, who leans towards a more critical approach to "hygge" and suggests several observations intended to unveil the "dark side" of hygge. To a certain extent "hygge" embodies a "positive perception of mediocrity" [Pessel, 2018, p. 41]. He goes further than J. P. Linnet and sees "hygge" not as a means of social control, but as a "tool of societal coercion" [Pessel, 2018 , p. 42]. Quite counterintuitively, hygge can simultaneously unite certain people whilst depriving others of this same social experience, seemingly constituting a "rationed access to full participation in culture" [Pessel, 2018]. He is quite skeptical of the widely-publicised assumption that Danes are the happiest people in the word [The Happy Danes, 2014]. Making a brief political detour into the past, he reminds the reader that although Denmark managed to create a positive image for the country internationally in the XX century, the beginning of the new millennium put this positivity to test by subjecting it to a set of actions that may have appeared strange or even illogical to a detached onlooker. These include: 1) the gradual dismantling of the Nordic welfare state model; 2) the Muhammad cartoons controversy in 2005; 3) negative attitude to refugees; 4 ) a dubious government initiative to pass a law that would enable the police to confiscate gold and jewelry 
from refugees and immigrants in order to cover the cost of their stay in Denmark [Pessel, 2018, p. 43].

Several stories that emerged in the British press seem to be especially noteworthy, as they, in one form or other, aspire to interpret Danish social values from an outsider's perspective. Just like many other societies, the British have been exposed to cultural marketing in the form of the Danish notion of "hygge", a concept which they did not know existed until fairly recently. This makes them relatively disinterested and unbiased objects coming from outside of the Danish socio-cultural environment. At the same time, English and Danish cultures demonstrate certain similarities in their evaluation of the ordinary as something appropriate and desirable, they also seem to share a negative attitude to excessive outward manifestations of feelings that are usually frowned upon on account of being out of place. An extensive and captivating portrayal of the "hidden" codes of English behaviour, which the author is referring to, can be found, for instance, in the bestseller Watching the English: the hidden rules of English behavior written by anthropologist Kate Fox [Fox, 2005].

Charlotte Higgins, The Guardian's chief writer for culture, published an illuminating and long read under the title of "The hygge conspiracy", which contains a warning against "hygge" - "the real thing is less cuddly than it seems" [Higgins, 2016]. Her findings are as follows: 1) "hygge" in its advertised rendition is a "wildly overhyped trend", this alone contradicts the essence of the concept as propagated (and has little in common with the ubiquitous "cashmere cardigans, wine, wallpaper" etc.); 2) the imperativeness and obtrusiveness of hygge cause discomfort; 3 ) "hygge" is oftentimes "mobilised" by far right (see below) politicians.

The article quotes Danish writer Dorte Nors and her compatriot journalist Lotte Folke Kaarsholm, who criticise "hygge" from different standpoints. Among other things, Nors claims that "hygge" is seldom used as an avoidance strategy to suppress unwanted emotions. She provides a fictionalised example, which boils down to the following - if one is confronted by the prospect of an unpleasant conversation, one can always try to make it less difficult by inviting the counterpart to enjoy themselves (in a "hyggelig" way), which sends a distinct signal as soon as one brings up some kind of unpleasant, but perhaps quite necessary topic, one can spoil the fragile "hygge". Norse equally admits to inconsistencies present in "hygge", one is almost obliged to uphold 
"hygge" in social gatherings, it is tacitly ill-advised to be unhappy and to make it visible to others, which invariably adds an element of nervousness to social interactions [Higgins, 2016].

The suppression of difference manifests itself in many ways. Regarding political agendas, Nors states that "hygge is part of the whole set-up of the radical right wing in Denmark" and hygge symbols tend to appear in commercials promoting their point of view. Higgins develops this line of thinking and fills in the missing link between innocuous "hygge" and the far-right movement - "if hygge is uniquely Danish, and hygge can only be enjoyed by insiders, then migrants and outsiders will destroy the nation's hyggelig atmosphere, and therefore effectively destroy Denmark". Lotte Kaarsholm offers another explanation as to why "hygge" excludes and how this is demonstrated at a state level - the social system devised by Nordic countries can only operate under strict conditions with a regulated influx of people from outside - "you have all these ideals of kindness on the inside, but for our solidarity to function, you need pretty tall walls" [Higgins, 2016].

An article written for The Telegraph by the columnist Judith Woods also speaks of the ambiguity of hygge, albeit her reasonings seem to be more intuitive, but just as valuable, because she merely uses "hygge" as a metaphor that helps to convey her point on a different matter altogether. It is called "Forget hygge - Brits should be embracing 'brygge" [Woods, 2016] - and by this she means the necessity to come to terms with the imminence of Brexit. The article contains the following passage:

Which is why we must close the ports and stem this tide of sub-Ikea tweeness, not least because the Danes - who passive-aggressively self-style themselves as the happiest people on earth - frown upon any controversial talk of current affairs when they are giving friends and family a claustrophobic group hygge.

('Вот почему мы должны закрыть илюзы и остановить волну сентиментальности, перестать тешить себя поделками в стиле Икея. Не в последнюю очередь потому, что датчане (которые пассивно-агрессивно считают себя самыми счастливыми людьми на свете), косо смотрят на полемические дискуссии о текущих событиях, когда заключают родственников и друзей в коллективные «удушевные» объятья”). 


\section{HYGGERACISME AND HYGGESEXISME: ORIGINS, MEANING, AND THE DIFFICULTIES OF TRANSLATING}

The dictionary of contemporary Danish language traces the first official appearance of the neologism "hyggeracisme" back to 2003 [Den danske ordbog] and offers the following definition:

det at bruge racistiske ord og give udtryk for fordomme vedr. personer af anden etnisk oprindelse på en måde som man selv synes er sjov og uproblematisk, men som er sårende og stødende for dem man taler om eller med

('the use of racist words and the expression of prejudice against people of other ethnic origin in a way one thinks is fun and unproblematic, but which is hurtful and offensive to those one is talking about or to');

('использование слов, носящих расистский характер, выражение предрассудков в отночении тии, иного этнического происхождения, которое само тицо считает забавным и беспроблемным, но ранящее и обижающее того, о ком идет речь ( того, кому это было обращено').

One of the examples the dictionary provides is rather eloquent:

hyggeracisme er, når vi danskere hygger os med de froekke ord

('hygge-racism is when we Danes indulge ourselves in the naughty words');

('hyggeracisme - это когда мы, датчане, забавляемся непристойными словами').

The necessity of investigating the nature of this word by placing an equal importance on both its linguistic and cultural aspects has not, as of yet, been adequately elaborated. An initial attempt has been made however by Maja Bodekær Black ("Hygge racism: "noget som man nok bruger mere end man tænker over") [Black, 2018]. The title unambiguously states that hyggeracisme is something that is used more frequently than one may think. It is quite telling though that the subtitle in English reads: "a qualitative study of well-intentioned racism” («расизм из благих намерений»).

The Danish language possesses another peculiar word "hverdagsnationalisme" ("everyday nationalism” or «бытовой национализм»), it is featured in Richard Jenkins' book on the Danish identity [Jenkins, 2014, p. 147]. However, the term has not yet succeeded in finding its way into the dictionary of contemporary Danish language. It is worth mentioning that Jenkins records a very peculiar tendency — some groups of young 
people (but not exclusively younger groups) often use the words "nationalisme" and "racisme" with somewhat of an ambiguous meaning:

en af de andre grunde til, at man tror, at vi er nationalister, er, at man tror, vi er racister

('one of the other reasons why they think we are nationalists is because they think we are racists')

('еще одна из причин, по которой люди думают, что мы националистьи, это то, что они думают, будто мы расисть')

jeg er en lille smule nationalistisk... Men fremmede er meget velkomne. Så lad vore med at kalde mig racist

('I'm a little bit nationalistic ... But foreigners are very welcome. So stop calling me racist')

('я немножечко националист... Но чужакам я всегда рада. Поэтому перестаньте меня называть расистом').

One can easily see that nationalism here is used in two meanings as an arguably acceptable sentiment of what is usually called national pride and as a clearly impermissible particular display of xenophobia:

jeg synes, at vi er meget nationalistiske. Vi er interesseret $i$ vores land, nogle mere end andre. De er dem, som er blevet så nationalistiske, at de er blevet racistiske, de tror, at Danmark kun er for danskerne...

('I think that we are very nationalistic. We are interested in our country, some more than others. There are some who have become so nationalistic, that they have become racists, they think that Denmark is only for the Danes...');

('я считаю, мы очень большие националисты. Мы интересуемся нашей страной, некоторые из нас - больше, чем другие. Есть те, у кого наичонализм перерос в расизм, и они считают, что Дания - только для датчан...').

Translating "hyggeracisme" presents several problems: 1) the impossibility of translating it with a single term that would be understood by the general public; 2) the necessity of disentangling the concepts of racism and nationalism from one another and determining the intention of the speaker; 3 ) the demand for providing an explanation as to why terms, such as racism and nationalism, that sound harsh to the Russian ear, were used in the source language, as these are not commonly used by speakers of Russian to define widespread and socially acceptable 
ideas, which are simultaneously undesirable outward manifestations of oneself in public discourse. Furthermore, the use of the words racism and nationalism can be misleading in terms of the nature of such an act, as it inadvertently may lead to the belief that what is meant here is an administrative infraction or a criminal offence.

The first circumstance is more or less obvious, the second, though, is much more complex, as racism in the strict sense of the word is an unscholarly belief about the superiority and inferiority of people that belong to different races. The use of the term in Danish does not necessarily imply one's adherence to such beliefs. Nationalism, it seems, is used in Danish with an array of meanings: 1) as a sense of belonging to a certain ethnicity, nowadays mostly negatively laden; 2) as a political ideology that operates under the presupposition that nation as a form of social unity is the key element in state building; 3 ) as a particular display of xenophobia.

As we can see, in many Danish examples no distinction is made, and both racism and nationalism may denote one's strong dislike for all things foreign rather inconsistently and in absence of a better or more concise term, these two are used.

According to article 20.3.1 of The Code of Administrative Offences of the Russian Federation, actions that constitute an incitement to hatred or enmity, as well as the abasement of the human dignity of a person or a group of persons on the basis of sex, race, nationality, language, origin, attitude to religion, as well as any other particular affiliation to any social group, committed in public, will be considered an administrative offence or regarded as corpus delicti by virtue of article 282 of The Criminal Code of the Russian Federation. Furthermore, discrimination, i.e. violation of rights, freedoms and/or the legal interests of a person on the basis of sex, race, nationality, language, origin and other committed by a person or by a person through their official position is punishable by law in accordance with article 136 of The Criminal Code of the Russian Federation.

Let's take a closer look at the following example found in the student newspaper Uniavis [Medstuderende: Vil du kaldes perker eller indvandrer?, 2019]:

mens hyggeracisme for nogen kan virke harmløst, så kan det alligevel godt have en negativ indflydelse, siger Ditte Marie Munch-Jurisic: »Selv om man selv synes, det er sjovt at ytre en bestemt joke, er det ikke sikkert, at den bliver modtaget 
på samme måde af modparten. Intentionen er ikke nødvendigvis at skade, men konsekvensen kan vere en helt anden. Derfor kan hyggeracisme vise sig problematisk

('while hygge racism may seem to be harmless to some people, it can still have a negative impact' says Ditte Marie Munch-Jurisic: "Although one thinks that it is fun to make this particular joke, it may not be perceived similarly on the receiving end. The intention is not necessarily to hurt, but the consequences can be quite different. This is why hygge racism can prove problematic')

('хотя кому-то шутки и подтрунивания с национальным подтекстом могут показаться безобидными, они все же могут оказать негативное воздействие. Дитте Марие Мунк-Юрисич говорит, что даже если кому-то кажется, что та или иная шутка забавна, это не значит, что собеседник воспримет это аналогичным образом, не всегда присутствует желание причинить вред, но последствия могут быть совершенно иными, и именно поэтому такое явление может создать проблемь').

The article broaches a multitude of similar situations, and it is more than likely impossible to pinpoint what exactly these jokes are pointing to or getting at - one's belonging to a certain ethnicity or a race. One can also conclude that the use of such words as "racisme" (расизм) and "nationalisme" (национализм) does not seem to convey what these terms usually imply in other languages. The context elucidates the intent behind the usage and allows us to understand that we should not characterise this as an antisocial deed or an act injurious to the public, but rather as a testament to, or an example of, bad manners or inappropriate forms of friendly banter. The addition of hygge- to the term, in fact, inculcates quite paradoxically, a positive implication in the mind of the speaker, which makes such an action less reprehensible as it engenders: 1) the establishment of interpersonal contact; 2) consolidation around the discussion on a certain topic; 3) the desire to defuse tension with a universal medium, i. e. humour, however out of place it may be.

Another wide used neologism, hyggesexisme, is not listed in The dictionary of contemporary Danish language, although in 2015 it was nominated by the Danish Broadcasting Corporation (DR) for word of the year, along with "flygtningestrøm" (stream of refugees) and several others [Fra 'Lovestorm' til 'Daesh' - se de 326 kandidater til ‘Årets ord 2015, 2015]. 
Here is an example of usage from Jyllands-Posten [Pabst, 2016]:

hyggesexisme er ligeså folkelig som X-factor... Hyggesexismen er verdens bedste icebreaker

('hygge sexism is just as popular as The X-factor is... Hygge sexism is the best icebreaker in the world')

('сексистские шутки - такое же популярное явление, как «Иксфактор»... Ничто так не помогает растопить тед как юмор такого poda').

On a formal level the term sexism exists in Russian, though it is rarely used. The emergence of the concept of "gender" alongside "sex" makes the translation of hyggesexisme even more problematic, because it may relate to the binary opposition between male and female sexes, or be applicable to a plethora of possibilities as "gender" encompasses a wide variety of subtypes. Using the adjective sexist (сексистский) instead of a noun may be a better option as the adjectival usage allows the notion to become a characteristic, and not necessarily a matter within the legal environment.

Such neologisms can be found in contemporary Danish fiction. Alle veje fører til moR a collection of e-mails, written by Maise Njor and her daughter Asta-Maja Njor Boisen [Njor Boisen, Njor, 2018] includes the following observation:

det varste ved Danmark er: Hygge. Hygge-racisme, hyggesexisme, jokes, der er mega strenge og hårde, men som man ikke må tage seriøst, for "det er jo bare for sjov"

'the worst thing about Denmark is: Hygge. Hygge racism, hygge sexism, jokes that are mega-terrible and hardhearted, but that one mustn't take seriously, because "it's just for fun")

('самое ужасное в Дании - Хюгге. Шуточки с сексистским или националистическим подтекстом, очень жесткие и стремные, но их запрещается воспринимать всерьез, так как они «просто для прикола»').

Research conducted in the Danish segment of the Internet has given us such occasionalisms as hyggenazisme (hygge nazism), hyggekommunisme (hygge communism), hyggesocialisme (hygge socialism), and hyggepessimisme (hygge pessimism). These examples illustrate the fact that all such neologisms necessarily contain some sort of political or psychological content, which gives them a social dimension, whereas 
"hygge" is meant to underline the peculiar Danish ways of dealing with these issues, usually when depicting various social groups, often from the charged perspective of a dominant ideology.

\section{CONCLUSION}

The article has explored a set of Danish neologisms containing the term "hygge", whereof the most frequently used are hyggeracisme and hyggesexisme, which gained popularity at the end of the XX and the beginning of the XXI century. Although they are predominantly used in the Danish media for the time being, there are reasons to believe that they may take hold in the language, as they convey a range of meanings and implications not covered by nationalism or sexism alone. Such heavily laden terms as racism and sexism paradoxically tie in with the Danish concept of "hygge", one of the key notions in Danish culture, which testifies to the fact that hygge should be understood in a broader and deeper sense, not simply limited to its superficial meaning, which has been recently broadcast and commercialised through popular lifestyle literature. The scope and the implications of "hygge" in the Danish culture have been analysed, its limiting and inclusive nature alike. Existing contextual differences regarding the perception of the terms 'nationalism', 'racism', and 'sexism' in Danish and Russian as shown above, make literal translation inadequate and underscore the importance of adopting the apposite interpretation of these composite Danish nouns and often necessitate the use of descriptive strategies when translating.

\section{REFERENCES}

Balslev L. The Little Book of Fika: The Uplifting Daily Ritual of the Swedish Coffee Break. Andrews McMeel Publ., 2018. 160 p.

Dunne L. Lagom: The Swedish Art of Balanced Living. Running Press Adult, 2017. $160 \mathrm{p}$.

Fox K. Watching the English: The hidden rules of English behavior. London: Hodder and Stoughton, 2005. $432 \mathrm{p}$.

Hansen J. F. The Proxemics of Danish Daily Life. Studies in Visual Communication. Volume 3, issue 1, spring 1976, p. 52-62.

Jenkins R. At vore dansk - identitet $i$ hverdagslivet. København: Museum Tusculanums Forlag og Richard Jenkins, 2014. 371 p. (In Danish) 
Krasnova E. V. The Concept of Hygge as a Part of the Danish Linguistic World Image. Skandinavskie chteniia 2014 goda. Etnograficheskie i kul'turno-istoricheskie aspekty. St. Petersburg, 2016. P. 541-548. (In Russian)

Levisen C. Cultural Semantics and Social Cognition: A Case Study on the Danish Universe of Meaning. Berlin; Boston, 2012. 333 p.

Linnet J. T. Money can't buy me hygge: Danish middle-class consumption, egalitarianism and the sanctity of inner space. Social Analysis: Journal of Cultural and Social Practice, 2011. Bd. 55. No. 2. P.21-44.

Livanova A.N. "Kos" and "Hygge": The Key Words of the Norwegian Culture. Gertsenovskie chteniia. RGPU University Publ., 2019. P. 222-224. (In Russian) Nylund J. Sisu: The Finnish Art of Courage. Running Press Adult, 2018. 160 p.

Pessel W. K. The Hygge Phenomenon. Between a lifestyle and nationalism. Przeglad Humanistyczny. Rok LXII. 2018. Nr. 2 (461). P. 35-48.

Rantanen M. Pantsdrunk: Kalsarikanni: The Finnish Path to Relaxation. Harper Design Publ., 2018. 176 p.

Russell H. The Year of Living Danishly: Uncovering the Secrets of the World's Happiest Country. Icon Books Publ., 2016. 354 p.

Thomsen Brits L. The Book of Hygge: The Danish Art of Living Well. Ebury Press, 2016. 192 p.

Tourell Søderberg M. Hygge: The Danish Art of Happiness. Michael Joseph Publ., 2016. 224 p.

Viking M. The Little Book of Hygge: Danish Secrets to Happy Living. New York, NY: William Morrow Publ., 2016. 240 p.

\section{DICTIONARIES AND INTERNET RESOURCES}

Black M. B. 'Hygge racism': "noget som man nok bruger mere end man tænker over". A qualitative study of well-intentioned racism. Sociologi, SOCK04 VT 18, kandidatuppsats. Sociologiska Institutionen, Lund Universitet, 2018. Available at: http://lup.lub.lu.se/luur/download?func=downloadFile\&recor$\mathrm{dOId}=8949314 \&$ fileOId=8949318 (accessed: 04.05.2020).

Den Danske Ordbog. Moderne dansk sprog. Hyggeracisme. Available at: https:// ordnet.dk/ddo/ordbog?query=hyggeracisme (accessed: 04.05.2020).

Fra 'Lovestorm' til 'Daesh' - se de 326 kandidater til ‘Årets ord 2015'. DR. Den 18. december 2015. Available at: https://www.dr.dk/nyheder/kultur/fra-lovestormtil-daesh-se-de-326-kandidater-til-aarets-ord-2015 (accessed: 04.05.2020).

Higgins Ch. The hygge conspiracy. The Guardian. 22 November 2016. Available at: https://www.theguardian.com/lifeandstyle/2016/nov/22/hygge-conspiracy-denmark-cosiness-trend (accessed: 04.05.2020).

Medstuderende: Vil du kaldes perker eller indvandrer? Uniavisen. Den 11. marts 2019. Available at: https://uniavisen.dk/medstuderende-vil-du-kaldes-perkereller-indvandrer/ (accessed: 04.05.2020). 
Pabst M.V. Hyggesexisme er ligeså folkelig som X-factor. Jyllands-Posten. Den 23. marts 2016. Available at: https://jyllands-posten.dk/debat/blogs/metteviktoriapabst/ECE8541107/hyggesexisme-er-ligesaa-folkelig-som-xfactor/ (accessed: 04.05.2020).

The Code of Administrative Offences of the Russian Federation No. 195-FZ of December 30, 2001 (With Amendments and Additions From August 2, 2019, Effective as of November 1, 2019). Available at: http://www.consultant.ru/ document/cons_doc_LAW_34661/(accessed: 04.05.2020).

The Criminal Code of the Russian Federation No. 63-FZ of June 13, 1996 (with Amendments and Additions from April 4, 2020, Effective as of April 12, 2020). Available at: http://www.consultant.ru/document/cons_doc_LAW_10699/ (accessed: 04.05.2020).

The Happy Danes. Exploring the reasons behind the high levels of happiness in Denmark. Ed. by Meik Viking. Happiness Research Institute, 2014. Available at: https://6e3636b7-ad2f-4292-b910-faa23b9c20aa.filesusr.com/ugd/928487_7f 341890e9484a279416ffbc9dc95ff4.pdf (accessed: 04.05.2020).

Woods J. Forget hygge - Brits should be embracing 'brygge'. The Guardian. 15 September 2016. Available at: https://www.telegraph.co.uk/women/life/ forget-hygge---brits-should-be-embracing-brygge/ (accessed: 04.05.2020).

\section{FICTION}

Njor M., Njor Boisen A.-M. Alle veje fører til MoR. København: Berlingske People's Press, 2018. 271 p. (In Danish)

\section{Юлия Авакова}

Московский государственный институт международных отношений (университет) Министерства иностранных дел Российской Федерации

\section{TЕНЕВАЯ СТОРОНА ДАТСКОГО НYGGE: НЕОЛОГИЗМЫ HYGGERACISME И НYGGESEXISMЕ, ИХ ЗНАЧЕНИЕ И ПРОБЛЕМЫ ПЕРЕВОДА}

Для цитирования: Avakova Yu. The dark side of Danish hygge: Neologisms hyggeracisme и hyggesexisme, their meaning and translation options // Скандинавская филология. 2020. Т. 18. Вып. 1. С. 5-20.

https://doi.org/10.21638/11701/spbu21.2020.101

Статья рассматривает концепт hygge, являющийся неотъемлемой частью датского языкового сознания. Недавно возникшие неологизмы hyggeracisme и hyggesexisme, получившие достаточно широкое распространение в датских СМИ, с одной стороны, включают в себя разные оттенки значений, присущих общепринятым трактовкам концепта hygge, с другой - демонстрируют частную его реализацию. В подавляющем большинстве случаев «теневая» сторона датского hygge становится предметом исключительно социологических исследований, несмотря на особую важность всестороннего понимания этого явления 
для осуществления адекватного перевода. Для более полного уяснения значения данных неологизмов необходимо не только определить границы самого концептa hygge, но и провести разграничение между положительными, нейтральными и отрицательными его проявлениями в общественной жизни. При более детальном рассмотрении оказывается, что содержание понятий "расизм» и «сексизм» в русском языке в существенной степени пересекается с датскими эквивалентами, однако, при включении вышеуказанных понятий в неологизмы hyggeracisme и hyggesexisme их значение подвергается существенной трансформации с размыванием значения, что делает буквальный перевод несостоятельным. Определить наиболее удачные стратегии перевода представляется возможным только с учетом интенции говорящего, ориентирующегося, как правило, на достаточно специфические датские социокультурные реалии. В статье представлены отдельные примеры употребления неологизмов hyggeracisme и hyggesexisme и даны возможные варианты перевода.

Ключевые слова: датский язык, hygge, hyggeracisme, hyggesexisme, неологизмы, расизм, национализм, сексизм, социолингвистика, перевод.

\section{Yulia Avakova}

Senior Lecturer,

Moscow State Institute of International Relations (University)

of the Ministry of Foreign Affairs of the Russian Federation,

76, pr. Vernadskogo, Moscow, 119454, Russia

E-mail: mp-july@yandex.ru

\section{Авакова Юлия Михайловна}

старший преподаватель,

Московский государственный институт международных отношений

(университет) Министерства иностранных дел Российской Федерации, Россия, 119454, Москва, пр. Вернадского, 76

E-mail: mp-july@yandex.ru 